\section{Infecção congênita pelo citomegalovírus: estudo realizado na Fundação Santa Casa de Misericórdia do Pará}

O citomegalovírus é um vírus de DNA pertencente à família Herpesviridae, subfamília Beta-herpesvirinae. Sua distribuição é universal e pode causar infecções congênitas e perinatais, assim como durante a infância e na idade adulta. É um dos principais patógenos responsáveis pela morbidade e mortalidade em pacientes imunocomprometidos. Foi estudada a incidência da infecção congênita pelo citomegalovírus, na maternidade da Fundação Santa Casa de Misericórdia do Pará, no período de novembro de 1994 a maio de 1995. A amostra trabalhada constou de 663 recém-nascidos e suas respectivas mães. O peso dos recém-nascidos variou de 900 a $5450 \mathrm{~g}$, com uma média de $3046 \mathrm{~g}$. Em $11,4 \%$ das crianças foi observado baixo peso ao nascer. A avaliação pelo isolamento do vírus da saliva dos 663 recém-nascidos, através da inoculação em células primárias de fibroblasto de prepúcio humano, mostrou 3,2\% (21) de positividade. A pesquisa de anticorpos IgM específicos para o CMV, através do método ELISA, utilizando-se sangue do cordão umbilical do mesmo grupo de recém-nascidos foi positiva em 2,1\% (14). Para o diagnóstico da infecção congênita pelo $\mathrm{CMV}$, a análise estatística pelo Teste de McNemar dos Pares Discordantes $(p)=0,0233$ e Teste do Qui-quadrado da Homogeneidade $(p)<0,01$ demonstrou que 0 isolamento do citomegalovírus da saliva foi mais sensível que a detecção de anticorpos IgM no sangue do cordão umbilical. Dos 21 recémnascidos infectados, $28,5 \%$ (6) apresentaram nas primeiras 24 horas de vida, sintomatologia sugestiva de infecção congênita. Os sinais e sintomas encontrados foram microcefalia (4), prematuridade (3), hepatoesplenomegalia (2), pequeno para a idade gestacional (2) e icterícia precoce (1). A pesquisa de anticorpos IgG específicos para o CMV, pelo método ELISA, foi positiva em $90,2 \%$ das puérperas. Das 21 mulheres que transmitiram o vírus para o concepto, foram detectados anticorpos IgM em 4. A entrevista pessoal com as mães dos recém-

\section{Congenital cytomegalovirus infection: a study carried out in the "Fundação Santa Casa de Misericórdia do Pará, Brazil"}

Cytomegalovirus (CMV) is a DNA virus classified in the Hespesviridae family and Betaherpesvirinae subfamily. It has a worlwide distribution and may cause congenital and perinatal infection, as well acquired infection in children and adults. CMV has been associated with high rates of morbidity and mortality among immunodeficient or immunosupressed patients. This investigation was carried out from November 1994 to May 1995 in the maternity of a local public hospital - "Fundação Santa Casa de Misericórdia do Pará" - and the main objective was to assess the incidence of congenital CMV infection among neonates in Belém, Brazil. We enrolled 663 newborns and their mothers to participate in our study. The weights of neonates ranged from 900 to $5450 \mathrm{~g}$ (mean of $3046 \mathrm{~g}$ ) and low birth weights were recorded in $11.4 \%$ of them. For diagnostic purposes, clinical specimens (spittle) were inoculated on to culture cell lines prepared from human foreskin fibroblasts, yielding virus isolation in $21(3.2 \%)$ of patients. Cord blood samples have been tested for the presence of CMV-specific IgM by using ELISA, with positive results in $14(2.1 \%)$ patients. Differences of sensitivities between these methods were analysed by using the McNemar' test (Comparing proportions in paired groups) and the (2 test of homogeneity, as appropriate. Virus isolation proved to be more sensitive than serology, with $p$ values of 0.0233 and less than 0.01 for the former and latter statistical tests, respectively. Six $(28.5 \%)$ among the 21 infected neonates were shown to be congenitally infected, presenting with typical signs and symptoms suchs as: microcephaly (4), prematurity (3), hepatosplenomegaly (2), low birth weight (2) and jaundice (1). Sera from mothers were also tested for the presence of CMV-antibody by ELISA. The detection of specific IgG was recorded in $90.2 \%$ of them, whereas $\mathrm{IgM}$ seropositivity was detected in $4(19.0 \%)$ of those 21 mothers of infected children. Data gathered

Recebido para publicação em 12/12/97. 
nascidos revelou nível socioeconômico baixo e assistência pré-natal deficiente, com $26,4 \%$ das puérperas sem nenhuma consulta durante 0 período gestacional. Em nossa amostra, a idade materna variou de 12 a 42 anos, com idade média de 22,2 anos, sendo que a idade das mães dos recém-nascidos infectados foi inferior a 25 anos. during routine interviews with mothers revealed low social economical level and indicated that $26.4 \%$ of them had no prenatal medical assistance. Their ages ranged from 12 to 42 years (mean age of 22.2) and all mothers of CMV-infected children were aged less than 25 years.

\section{Judith Weirich}

Tese apresentada ao Núcleo de Medicina Tropical da

Universidade Federal do Pará para obtenção do Título de Mestre.

Belém, PA, Brasil, 1997 